\title{
Penerapan Sistem Keuangan Berbasis Digital pada UMKM di Kecamatan Batujajar, Kabupaten Bandung Barat
}

\author{
Eka Yulianti ${ }^{1}$, Abdul Ahmad Hafidh Nurmansyah ${ }^{2}$, Asep Kurniawan ${ }^{3}$, Leni Evangelista ${ }^{4}$, \\ Faizal Fardhani Sigarlaki ${ }^{5}$ \\ 1,2,3,4,5Program Studi Manajemen Fakultas Ekonomi dan Bisnis, Universitas Jenderal Achmad Yani \\ *e-mail: eka.yulianti@lecture.unjani.ac.id ${ }^{1}$, abdul.ahmad@lecture.unjani.ac.id ${ }^{2}$, \\ asep.kurniawan@lecture.unjani.ac.id ${ }^{3}$, leni.evangalista@lecture.unjani.ac.id ${ }^{4}$, \\ faizal.sigarlaki@lecture.unjani.ac.id ${ }^{5}$
}

\begin{abstract}
The covid-19 pandemic is an avodable condition in the world. One of the business affected is MSMES at Batujajar District, West Bandung Regency. In addition, this also exacerbated by a less than optimal financial system, so that MSME owners do not know for sure their financial condition. Based on this statements, MSMES need training and assistance related to financial records. This is important because it can be one of the triggers for MSMEs to be able to maintain their business existence. The PKM team designed a simple financial system and used training and assistance methdos to provide knowledge about the system. The results showed that MSMEs were able to understand and carry out digital financial system using either a computer or mobile phone. The capabilities they have are expected to be one of the triggers for development and existence of the business.
\end{abstract}

Keywords: MSMEs, Covid-19, Financial System, Digital

\begin{abstract}
Abstrak
Pandemi covid-19 merupakan kondisi yang tidak dapat dihindari dewasa ini. Salah satu usaha yang terkena dampaknya adalah UMKM. Begitu pun UMKM yang bergerak di bidang industri makanan di Kecamatan Batujajar Kabupaten Bandung Barat. Selain itu, hal ini juga diperburuk oleh sistem pencatatan keuangan yang kurang optimal sehingga para pemilik UMKM tidak mengetahui secara pasti kondisi keuangannya. Atas dasar tersebut artinya UMKM membutuhkan pelatihan dan pendampingan terkait pencatatan keuangan. Hal ini penting karena dapat menjadi salah satu pemicu UMKM untuk dapat mempertahankan eksistensi bisnisnya. Tim PKM merancangkan sebuah sistem keuangan sederhana dan menggunakan metode pelatihan dan pendampingan untuk memberikan pengetahuan terkait sistem tersebut. Hasil menunjukkan bahwa para UMKM pada akhirnya mampu memahami dan melakukan pencatatan keuangan berbasis digital baik dengan menggunakan komputer maupun handphone. Atas kemampuan yang mereka miliki diharapkan dapat menjadi salah satu pemicu pengembangan dan eksistensi usahanya terlebih dalam kondisi pandemi yang melanda dewasa ini.
\end{abstract}

Kata kunci: UMKM, Covid 19, Sistem Keuangan, Digital

\section{PENDAHULUAN}

Pandemi Covid-19 dewasa ini telah menyebar ke seluruh penjuru dunia. Virus ini mulai terdeteksi pertama kali pada awal Desember 2019 dan muncul di pasar hewan dan makanan laut di Kota Wuhan, Tiongkok. Hal ini menjadi ancaman bagi masyarakat di seluruh dunia karena tingkat penyebarannya yang cepat dan banyak menimbulkan korban jiwa hanya dalam waktu dua pekan. Selain itu, pandemi ini juga menyebabkan dampak yang sangat besar terhadap berbagai aktivitas perekonomian, meskipun sejauh mana dampak sebenarnya belum diketahui. Secara lebih spesifik, kondisi pandemi ini memberikan dampak menurunnya penjualan pada UMKM industri produk roti dan kue di daerah Batujajar Kabupaten Bandung Barat.

Berdasarkan potensi wilayah Kecamatan Batujajar secara fisik, sosial dan ekonomi, pengusaha roti dan kue ini memiliki potensi yang baik. Bersumber dari data Rencana Program Investasi Jangka Panjang Menengah Kabupaten Bandung Barat (RPIJM) 2015-2019. Kecamatan Batujajar memiliki luas wilayah 34,04 km², dengan jumlah desa sebanyak 7 desa. Distribusi PDRB Kabupaten Bandung Barat atas Dasar Harga Berlaku Menurut Pengeluaran tahun 2016 pada poin pengeluaran konsumsi rumah tangga sebesar 65,80\%. Melihat status pekerjaan di Kabupaten Bandung Barat, masyarakat disana didominasi oleh buruh/ karyawan/ pegawai yakni sebanyak 
251.878 orang pada tahun 2020 (BPS, 2020). Hal ini mengindikasikan bahwa wilayah tersebut memiliki potensi yang baik akan pengembangan UMKM industri makanan khususnya roti dan kue terkait dengan luasnya pangsa pasar daerah ini. Selain itu, secara ekonomi masyarakat sebagian besar adalah pekerja yang memiliki kemampuan secara ekonomi untuk menjadi konsumen dari produk-produk UMKM.

UMKM yang menjadi objek kegiatan pengabdian masyarakat terdiri atas 5 UMKM yang produknya adalah kue, bolu dan atau roti, serta katering. Para pemilik UMKM ini juga tergabung dalam komunitas kuliner Batujajar yang menjadi jejaring mereka dalam memasarkan produk. Kegiatan produksi pada UMKM ini sebagian besar dilakukan oleh pemilik itu sendiri dan meskipun dibantu oleh tenaga kerja, tenaga kerja tersebut dapat berasal dari pihak keluarga atau kerabat. Selain itu, dalam hal distribusi produk beberapa UMKM memanfaatkan jasa reseller untuk mendorong dan meningkatkan penjualannya. Lebih lanjut, terdapat juga UMKM yang memiliki toko dengan satu orang karyawan penjaga toko.

Permasalahan utama yang terjadi pada UMKM di daerah Batujajar adalah kurangnya pengetahuan mengenai bagaimana cara melakukan pencatatan keuangan. Sebagian besar pencatatan keuangan dilakukan secara manual dan sangat terbatas dalam pelaksanaannya. Selain itu, pencatatan keuangan tidak konsisten dilakukan karena terkendala waktu dan pengetahuan tentang bagaimana melekukan pencatatan keuangan yang dapat dilakukan secara efektif. Apabila hal tersebut dibiarkan maka akan menjadi ancaman bagi keberlangsungan usaha. Di sisi lain, pencatatan keuangan sangat diperlukan untuk mengetahui kinerja dan informasi mengenai keuangan yang terjadi dalam sebuah periode pada suatu usaha. Pencatatan yang masih dilakukan secara manual tentu dapat menimbulkan ketidakakuratan dalam penghitungan pendapatan dan pengeluaran yang pada akhirnya berdampak pada laporan keuangan. Laporan keuangan seharusnya menjadi kebutuhan bagi setiap unit usaha, terutama bagi pemilik usaha, mengingat manfaat yang dapat diperoleh bagi keberlanjutan usaha itu sendiri. Kondisi UMKM terkait pencatatan keuangan di daerah Batujajar tersebut relevan dengan pernyataan (Solikah, dkk, 2017) bahwa kesadaran mengenai pentingnya pembukuan dan laporan keuangan dikalangan wirausahawan, terutama kelas menengah ke bawah masing kurang. Padahal Laporan keuangan adalah tolok ukur dalam menilai kesehatan usaha [Sherly \& Pinatik, 2015).

Atas dasar tersebut UMKM perlu memperhatikan pengelolaan keuangannya baik dalam hal penerimaan maupun pengeluaran sehingga UMKM dapat mengambil keputusan yang tepat untuk bertahan. Hal ini mendasari kegiatan pengabdian kepada masyarakat yang akan dilakukan. Dengan adanya pelatihan dan pendampingan tentang sistem pencatatan keuangan berbasis digital yang baik diharapkan dapat membantu UMKM untuk tetap dapat mempertahankan eksistensinya. Hal ini juga, sejalan dengan Tri Dharma Perguruan Tinggi bahwa pengabdian kepada masyarakat harus memberikan dampak yang positif bagi objek pengabdiannya.

Dalam kondisi pandemi covid-19 dewasa ini, masalah yang dihadapi oleh UMKM adalah kesulitan pencatatan keuangan karena kurangnya pemahaman di bidangnya. UMKM belum dapat melakukan pencatatan pemasukan yang berasal dari penjualan dan pengeluaran yang berasal dari biaya-biaya yang yang diperlukan untuk kegiatan operasional, sehingga belum dapat menentukan laba/rugi dengan benar. Sehingga pembatasan masalah pada kegiatan pengabdian masyarakat ini adalah bagaimana sistem keuangan berbasis digital dapat diterapkan pada UMKM industry makanan produk roti dan kue di Kecamatan Batujajar Kabupaten Bandung Barat.

Program pengabdian kepada masyarakat ini bertujuan untuk mewujudkan penerapan pengelolaan keuangan berbasis digital. Diharapkan dengan adanya pelatihan dan pendampingan ini, UMKM dapat mengelola keuangan menjadi lebih baik karena diupayakan untuk dapat melakukan pencatatan keuangan yang baik. Pengelolaan yang baik tersebut salah satunya dapat dilihat dari adanya laporan kas, laporan buku besar, laporan laba rugi dan neraca. Usaha

Mikro Kecil dan Menengah (UMKM) merupakan usaha yang berorientasi laba dan berfokus pada peningkatan kesejahteraan masyarakat dengan cara menciptakan lapangan kerja baru (Wahyuningsih, 2019). Menurut Sedyasturi (2018) Pemerintah terus berusaha untuk 
mengembangkan usaha para UMKM. Upaya peningkatan kualitas UMKM tersebut salah satunya adalah pembuatan laporan keuangan yang baik (Mulyani, 2014). Dengan adanya laporan keuangan yang lengkap dan baik, UMKM dapat menganalisis yang kemudian dapat digunakan sebagai dasar keputusan atau kebijakan dimasa yang akan dating (Ningtiyas, 2017). Menurut Kurniawan (2020) UMKM di Indonesia pada umumnya belum melkaukan pencatatan transaksi bisnisnya sehingga UMKM banyak yang tidak memiliki laporan keuangan. Dengan demikian perihal pelatihan dan pendampingan pencaatan keuangan pada UMKM perlu dilakukan terutama dengan sistem informasi yang mudah digunakan (Jansori, 2018). Pelatihan pencatatan keuangan perlu dilakukan pada UMKM karena hal tersebut merupakan salah satu strategi bisnis, dan dari laporan keuangan itu UMKM dapat mnyusun strategi baik dalm jangka pendek dan jangka Panjang. Hal ini sejalan dengan pernyataan Setiyawati \& Hermawan (2018) bahwa strategi MM untuk meningkatkan skala bisnisnya adalah dengan penyusunan laporan keuangan.

Manajemen keuangan dapat dikatakan sebagai suatu seni dan ilmu pengetahuan terkait pengelolaan uang. Setiap individu dan organisasi menghasilkan uang dan membelanjakan atau menginvestasikan uang Gitman (2015). Selain itu, Manajemen keuangan merupakan proses pengaturan aktivitas atau kegiatan keuangan dalam suatu organisasi yang ada di dalamnya termasuk kegiatan perencanaan, analisis, dan pengendalian terhadap kegiatan keuangan yang biasanya dilakukan oleh manajer keuangan Mulyawan (2015). Tujuan dari manajemen keuangan itu sendiri adalah untuk menghasilkan keuntungan atau laba maksimal. Tujuan menghasilkan keuntungan disini agar perusahaan mempunyai nilai yang tinggi serta dapat mensejahterakan para pemegang saham. Selain itu, tujuan manajemen keuangan lainnya yaitu untuk menjaga likuiditas dan profitabilitas Musthafa (2017).

Lebih lanjut, laporan keuangan memberikan informasi mengenai aktivitas keuangan perusahaan yang bermanfaat bagi pemakai laporan keuangan. Pihak yang berkepentingan berupa pihak intern dan pihak ekstern perusahaan yang mempunyai kebutuhan berbeda dari informasi yang disajikan dalam laporan keuangan tersebut. Manajemen puncak sebagai pihak intern memerlukan informasi dari laporan keuangan sebagai bahan pertimbangan dalam pengambilan keputusan yang akan bermanfaat bagi perkembangan perusahaan. Sedangkan investor sebagai pihak ekstern memerlukan informasi dari laporan keuangan sebagai bahan pertimbangan untuk membeli atau menjual saham yang dimilikinya. Laporan keuangan itu sendiri dalam PSAK No. 1 (Revisi 2015) adalah suatu penyajian terstruktur dari posisi keuangan dan kinerja keuangan suatu entitas. Sedangkan menurut Fahmi (2015), laporan keuangan adalah suatu informasi yang menggambarkan kondisi keuangan suatu perusahaan, dan lebih jauh informasi tersebut dapat dijadikan sebagai gambaran kinerja keuangan perusahaan tersebut." Kemudian menurut Kieso, Weygandt and Warfield (2011:5), laporan keuangan adalah financial statement are the principal means through which a company communicate it's financial information to those outside it. The statement provide a company history quantified in money terms. Berdasarkan beberapa definisi tersebut sampai pada pemahaman penulis bahwa laporan keuangan merupakan hasil akhir dari proses akuntansi yang memberikan informasi mengenai kondisi keuangan perusahaan. Informasi dari laporan keuangan perusahaan digunakan sebagai bahan pertimbangan pengambilan keputusan bagi pihak-pihak yang berkepentingan baik itu pihak internal maupun eksternal.

Selanjutnya, Astuti (2019) mengatakan bahwa laporan keuangan dapat disusun sesuai dengan format yang ditentukan dengan data diperoleh dan pencatatan sebelumnya dengan bantuan kertas kerja. Berikut ini ada beberapa komponen informasi laporan keuangan yang bila perlu disajikan yaitu: 1 . Nama perusahaan pelapor atau identitas lainnya. 2. Cakupan laporan keuangan (berupa entitas). 3. Tanggal atau periode yang dicakup oleh laporan keuangan. 4. Mata uang pelaporan. 5. Satuan angka yang digunakan dalam penyajian laporan keuangan. Komponen laporan keuangan itu sendiri utamanya adalah Neraca dan Laporan Laba rugi. Menurut Astuti (2019), Neraca atau balance sheet adalah laporan yang menyajikan sumber-sumber ekonomis dari suatu perusahaan atau aset kewajiban- kewajiban atau utang, dan hak para pemilik perusahaan yang tertanam dalam perusahaan tersebut atau ekuitas pemilik suatu saat tertentu. Neraca harus disusun secara sistematis sehingga dapat memberikan gambaran mengenai posisi 
keuangan perusahaan, Sadeli (2011). Komponen berikutnya adalah laporan laba rugi, dimana laporan ini merupakan gambaran kinerja perusahaan dalam menghasilkan keuntungan. Pada dasarnya laporan ini membandingkan antara jumlah pendapatan dengan biaya-biaya yang dikeluarkan dalam suatu periode tertentu. Laporan keuangan juga memuat laporan arus kas atau laporan perubahan posisi keuangan yang menyajikan informasi aliran kas masuk atau keluar bersih pada suatu periode, hasil dari tiga kegiatan pokok perusahaan adalah operasi, investasi, dan pendanaan, Astuti (2019). Singal dkk (2015) mengatakan bahwa aliran kas diperlukan terutama untuk mengetahui kemampuan perusahaan yang sebenarnya dalam mengetahui kewajiban-kewajibannya. Dengan melihat laporan arus kas, dapat diketahui jumlah arus masuk dan keluar dalam satu minggu, bulan atau tahun. Selain itu, dapat diketahui jumlah keuntungan atau kerugian dengan melihat saldo akhir setiap minggu, bulan atau tahun. Pada umumnya UMKM hanya mengira-ngira dalam hal laba rugi, perilaku pemilik UMKM yang demikian dapat memperlambat perkembangan usaha (Savitri \& Saifudin, 2018).

Seiring dengan perkembangan ilmu pengetahuan dan teknologi, sistem pencatatan keuangan menjadi sesuatu yang dinamis mengikuti perkembangan IPTEK tersebut. Pencatatan keuangan kini tidak hanya dapat dilakukan secara manual, namun dapat berbasis digital. Menurut Aini, Rahardja, Arribathi, \& Santoso (2019), cloud accounting atau akuntansi online merupakan salah satu sarana penunjang pencatatan laporan keuangan yang bisa di akses secara online dimana perkembangan layanan ini berguna untuk memudahkan proses pelaksanaan dan meningkatkan efisiensi. Sasaran layanan ini adalah kemudahan pengelolaan keuangan usaha secara terperinci bagi masyarakat awam yang tidak mempunyai ilmu di bidang akuntansi. Bagi akuntan, cloud accounting mempermudah dalam memperoleh laporan terhadap manajemen dan bisa menghemat waktu dalam melakukan perhitungan karena dengan adanya cloud accounting bisa meminimalisir kesalahan dalam perhitungan dan tidak memakan waktu lama karena tidak perlu melakukan perhitungan secara konvensional, dan cloud accounting mempunyai kelebihan, yakni biaya yang murah (lowered cost). Kemudahan penggunaan sistem keuangan ini sejalan dengan pernyataan Nasution \& Hasan (2021) bahwasannya dengan sistem informasi dapat lebih mengefektifkan dan mengefisienkan pengguna dalam melaksanakan aktivitasnya.

\section{METODE}

Metode yang digunakan dalam pengabdian masyarakatnya khususnya dalam mewujudkan penerapan system keuangan berbasis digital adalah sebagai berikut:

1) Memberikan pemahaman tentang pentingnya pencatatan keuangan melalui sebuah pelatihan

2) Memberikan pemahaman konsep mengenai laporan Keuangan melalui sebuah pelatihan.

3) Membekali keterampilan penggunaan sistem keuangan digital melalui sebuah pelatihan dan pendampingan

Evaluasi keberhasilan kegiatan pengabdian kepada masyarakat ini dilakukan satu minggu sekali, denga kriteria UMKM telah bisa menjalankan sistem keuangan tersebut. Adapun indikator dalam evaluasi ini adalah UMKM sudah bisa input transaksi dan membaca laporan keuangan. Tolok ukur dalam evaluasi program ini, UMKM dapat melakukan secara rutin dan teratur baik dalam hal input transaksi maupun melakukan pemantauan terhadap laporan keuangannya.

\section{HASIL DAN PEMBAHASAN}

Kegiatan pengabdian masayarkat yang bertujuan untuk mewujudkan penerapan sistem keuangan berbasis digital pada UMKM industri makanan di Kecamatan Batujajar dilakukan melalui sebuah pelatihan dan pendampingan secara online melalui media zoom dan offline. Kegiatan tersebut sudah dilaksanakan sesuai dengan perencanaan kegiatan dan dengan berbagai luaran yang ditargetkan. Adapun kegiatan tersebut adalah sebagai berikut:

1. Memberikan pemahaman tentang pentingnya pencatatan keuangan

Pada tahap ini peserta pengabdian masyarakat diberikan pemahaman terkait pentingnya pencatatan keuangan bagi keberlangsungan usaha. Pencatatan keuangan yang termasuk 
didalamnya mencatat transaksi-transaksi penerimaan dan pengeluaran sangat penting dilakukan oleh UMKM. Hal tersebut pada akhirnya bertujuan untuk membuat laporan keuangan secara komprehensip terkait usaha yang dijalankan. Pada sesi ini, juga dijelaskan kepada peserta terkait Cash of Account (COA) pada kegiatan penerimaan dan pengeluaran. Selain itu, peserta diajak proaktif untuk menyampaikan apa saja kira-kira transaksi-transaksi yang dilakukan sehingga hal ini dapat dikelompokkan menjadi sebuah Cash of Account (COA) tertentu. Penyampaian materi pada masing-masing sesi disertai dengan tanya jawab dan diskusi sehingga peserta pelatihan dapat memahami materi yang diberikan sebagai landasan pada saat praktek pembuatan atau penyusunan laporan keuangan. Berikut ini merupakan kegiatan pelatihan yang dilakukan dengan UMKM induustri makanan produk roti dan kue sebagai peserta:

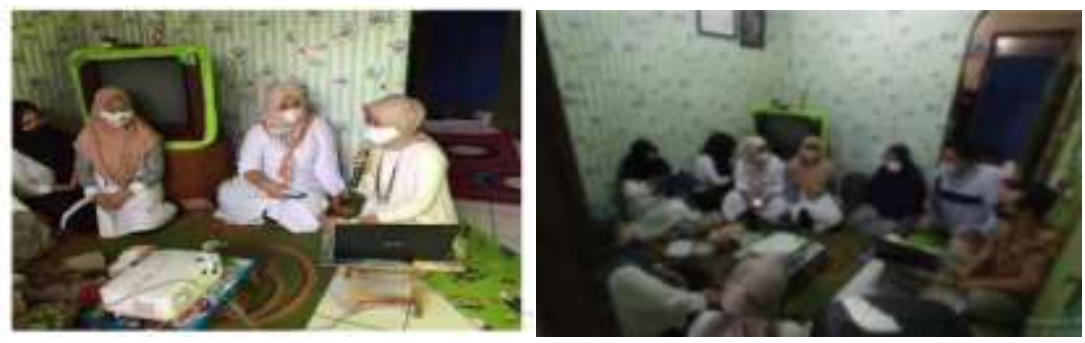

Gambar 1. Kegiatan Pelatihan

2. Memberikan pemahaman konsep mengenai laporan Keuangan

Pada tahap ini, peserta diberikan pemahaman terkait jenis -jenis laporan keuangan utama yang ada dalam sebuah perusahaan. Pemateri juga memberikan contoh-contoh sederhana laporan keuangan yang dapat diterapkan di sebuah UMKM. Laporan keuangan utama pada dasarnya adalah laporan laba rugi dan neraca. laporan laba rugi adalah laporan keuangan yang menggambarkan hasil usaha perusahaan dalam suatu periode tertentu (Kasmir, 2018). Selisih antara pendapatan dan biaya merupakan laba yang diperoleh atau rugi yang diderita perusahaan. Laporan laba rugi menyajikan pendapatan dan biaya serta laba atau rugi bersih yang dihasilkan selama suatu periode waktu tertentu. Selain itu, Laporan laba rugi merupakan suatu laporan yang sistematis tentang penghasilan, biaya, rugi laba yang diperoleh oleh suatu perusahaan selama periode tertentu. Biaya itu sendiri terdiri atas bahan baku, biaya tenaga kerja, dan biaya overhead pabrik. Berdasarkan hasil diskusi dengan objek kegiatan pengabdian masayarakat dengan produknya adalah roti dan kue maka biaya bahan baku adalah biaya yang dikeluarkan untuk membeli bahan-bahan seperti terigu dan telur. Selanjutnya dalam hal biaya tenaga kerja, sebagian besar UMKM di Batujajar ini tidak memperhitungkan komponen ini, karena yang melakukan kegiatan produksi dan sebagainya adalah pemilik UMKM itu sendiri. Kemudian, biaya overhead pabrik adalah biaya selain bahan baku dan tenaga kerja yang meliputi bahan penolong, biaya angkut, biaya penyusutan dan lain lain.

Kemudian terkait neraca, peserta juga diberikan pemahaman bahwa neraca merupakan gambaran posisi keuangan suatu usaha. Neraca merupakan laporan yang menunjukkan posisi keuangan perusahaan pada tanggal tertentu (Kasmir, 2018). Pos-pos yang ada dalam neraca yang juga disosialisasikan kepada peserta adalah sebagai berikut:

a. Aktiva, tidak terbatas pada kekayaan perusahaan yang berwujud saja, tetapi juga termasuk pengeluaran-pengeluaran yang belum dialokasikan atau biaya yang masih harus dialokasikan pada penghasilan yang akan datang, serta aktiva yang tidak berwujud lainnya.

b. Hutang adalah semua kewajiban keuangan perusahaan kepada pihak lain yang belum terpenuhi, dimana hutang ini merupakan sumber dana atau modal perusahaan yang berasal dari kreditor.

c. Modal adalah merupakan hak atau bagian yang dimiliki oleh pemilik perusahaan yang ditunjukkan dalam pos modal (modal saham), surplus dan laba yang ditahan. Atau kelebihan nilai aktiva yang dimiliki oleh perusahaan terhadap seluruh hutang-hutangnya. 
Selanjutnya, pada tahap ini juga dijelaskan laporan keuangan yang merupakan turunan dari laporan keuangan utama yaitu laporan arus kas dan neraca saldo. Hal ini dijelaskan karena akan berkaitan dengan sistem keuangan digital yang telah dirancang khusus untuk memfasilitasi UMKM agar lebih mudah melakukan pencatatan keuangan dan menghasilkan laporan keuangan secara otomatis. Laporan keuangan ini sangat penting bagi UMKM untuk dapat secara berkesinambungan memantau kondisi usahanya apakah megalami keuntungan atau kerugian. Sehingga dengan begitu diharapkan UMKM dapat melakukan tindakan preventif dalam mencegah kebangkrutan.

3. Membekali keterampilan penggunaan sistem keuangan digital melalui sebuah pelatihan dan pendampingan.

Tahap ini merupakan kegiatan inti dalam rangka mewujudkan penerapan sistem keuangan berbasis digital. Adapun kegiatan-kegiatan pada tahap ini adalah sebagai berikut:

1) Mensosialisaikan dan memberikan gambaran kepada peserta terkait sistem keuangan digital yang telah dirancang khusus oleh tim pengabdian masyarakat.

Sistem keuangan digital telah dirancang khusus untuk memfasilitasi UMKM agar dapat efektif dalam melakukan pencatatan keuangan. Adapun fitur-fitur yang terdapat pada system keuangan tersebut adalah:

a. Pengguna sistem pada UMKM dapat lebih dari satu.

b. Pembuatan chart of account (COA) yang dapat disesuaikan dengan kebutuhan UMKM.

c. Transaksi penerimaan, pengeluaran dan mutase antar rekening.

d. Laporan keuangan terdiri dari buku besar, laporan laba rugi dan neraca.

Berikut ini adalah tampilan dari sistem keuangan tersebut:

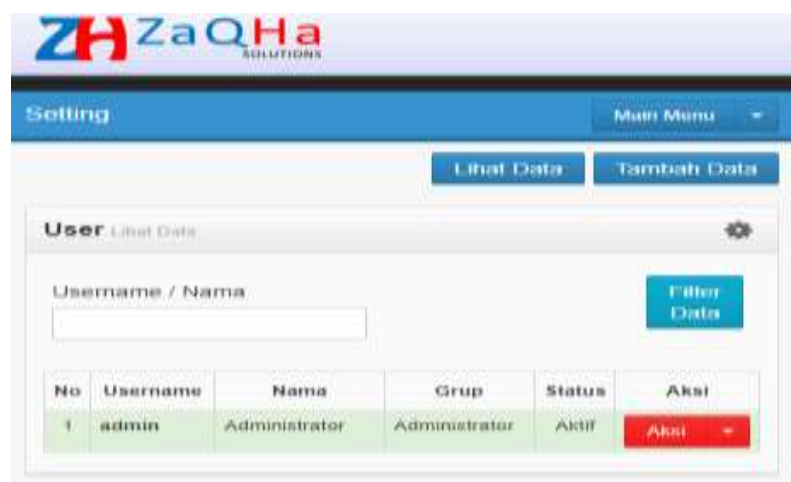

Gambar 2. User

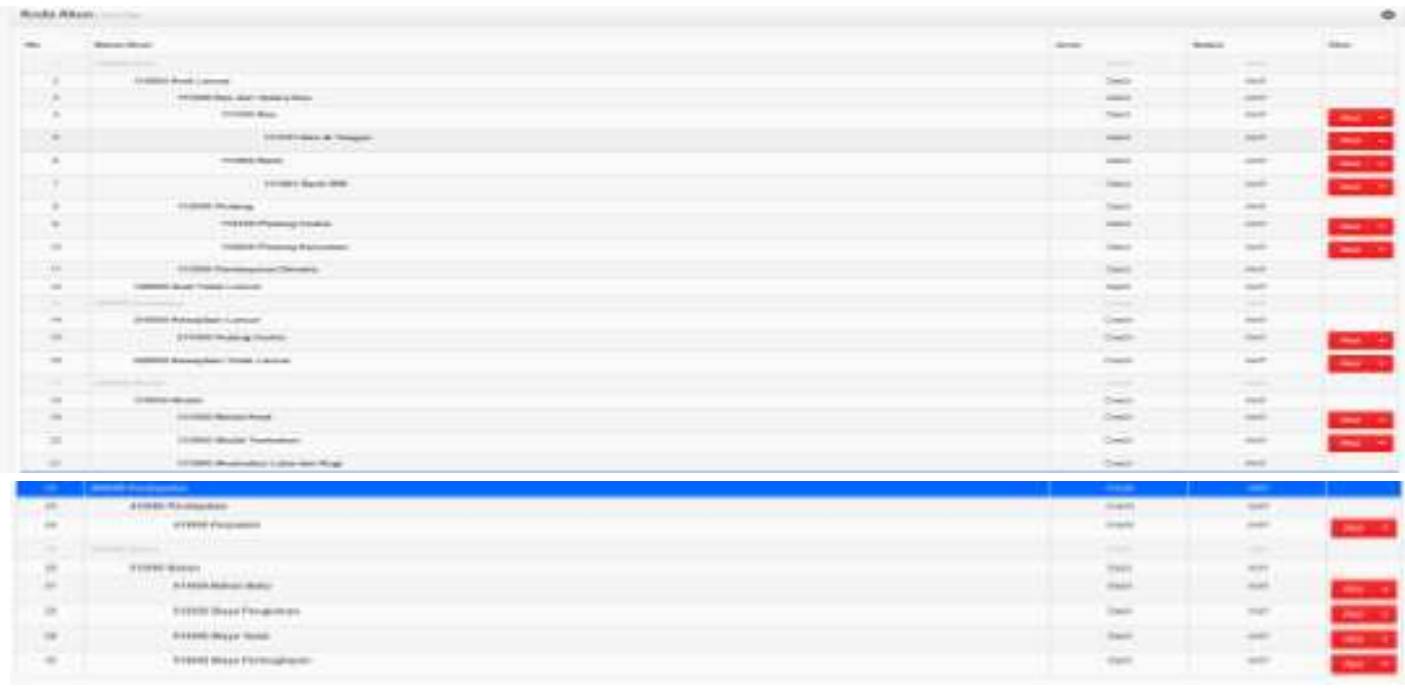

Gambar 3 Chart of Account 


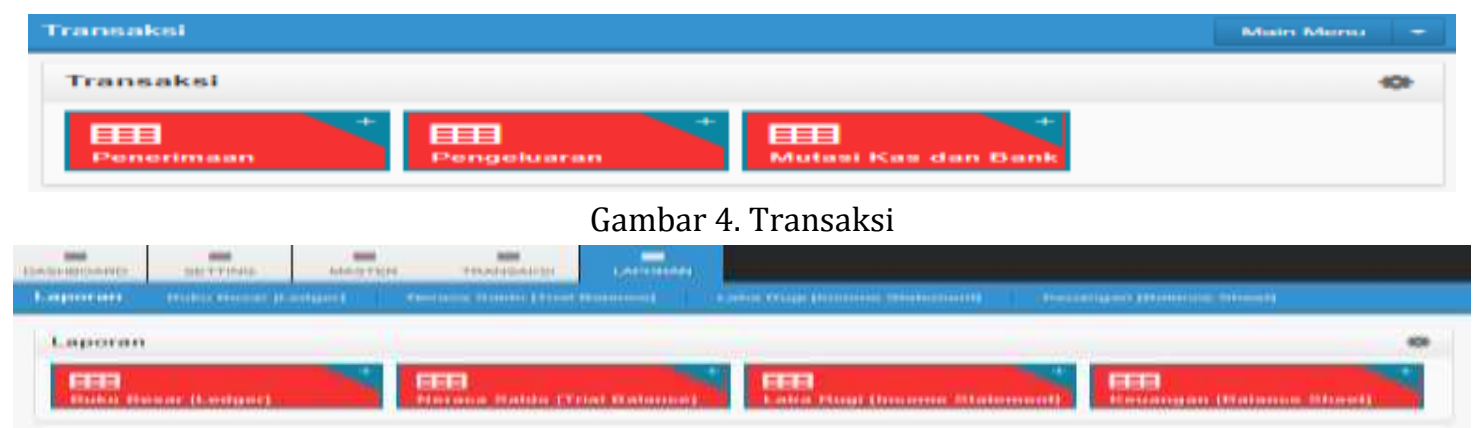

Gambar 5. Jenis-Jenis Laporan Keuangan

2) Memberikan pelatihan pencatatan transaksi

Pelatihan yang diselenggarakan kepada UMKM salah satunya adalah pencatatan transaksi. Pelatihan ini berfokus pada melatih agar UMKM terampil dalam pencatatan keuangan. Selain keterampilan juga UMKM diharapkan dapat menginput transaksi keuangan dengan benar. Hal yang pertama dilakukan dalam pelatihan pencatatan transaksi ini adalah dengan mewawacarai UKMK untuk dapat mengetahui chart of account yang akan digunakan. Selanjutnya diadakan pelatihan input transaksi yang terdiri dari penerimanaan dan pengeluaran. Berikut ini merupakan laporan penerimaan dan pengeluaran pada bulan Juli 2021.

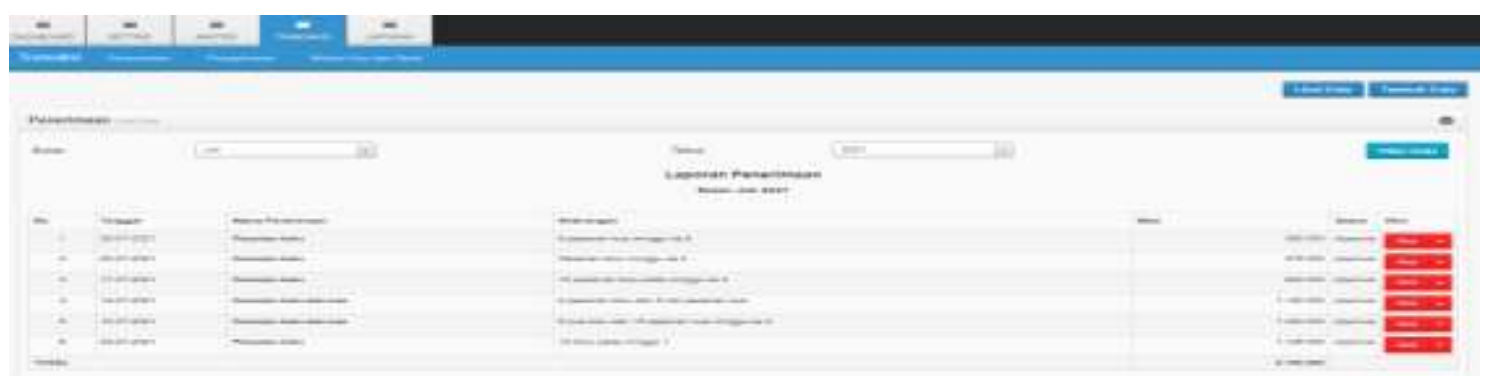

Gambar 6. Penerimaan Kas

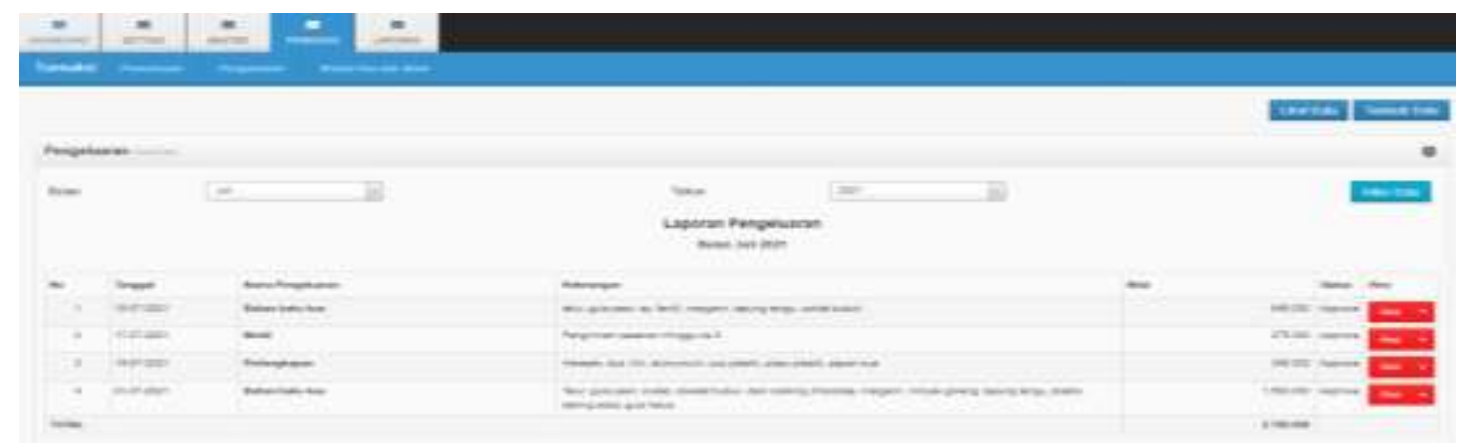

Gambar 7. Pengeluaran Kas

3) Memberikan pelatihan terkait pemahaman output laporan keuangan. Pelatihn berikutnya adalah tentang membaca laporan keuangan. Hal ini dituukan agar UMKM dapat mengambil keputusan dengan benar dengan melihat kondisi laporan keuangan. Laporan keuangan terdiri dari buku besar, laporan laba rugi dan neraca. Adapun tampilan dari laporan keuangan tersebut adalah sebagai berikut.

a. Buku Besar

Buku besar pada laporan keuangan dapat digunakan untuk melihat secara detail mengenai pergerakan transaksi. Dengan adanya laporan buku besar ini, UMKM dapat menjadikan informasi untuk mengambil keputusan dalam bisnisnya. Setiap COA yang telah diinput kedalam sistem maka dapat dilihat detail transaksinya pada buku besar ini. 


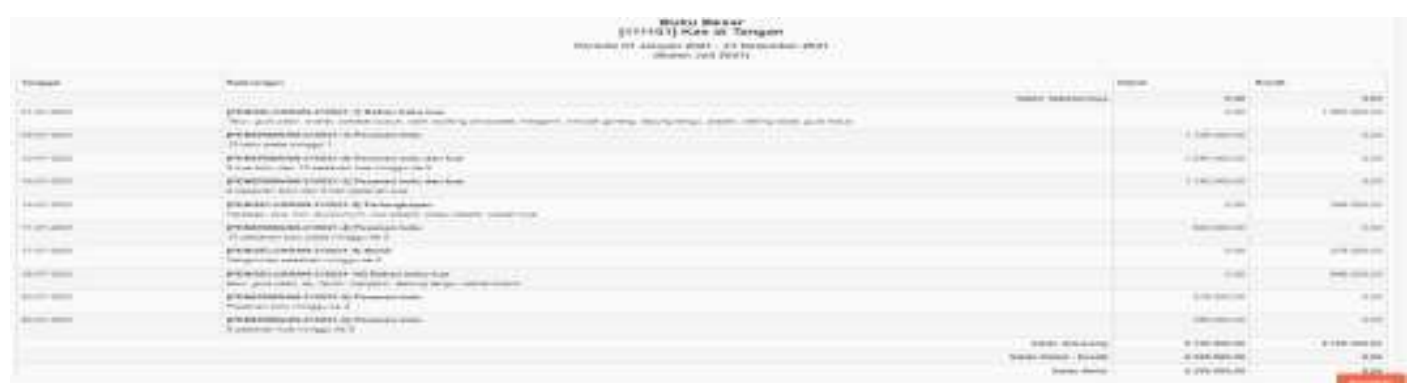

Gambar 8. Buku Besar

b. Laporan Laba Rugi

Laporan laba rugi merupakan laporan yang penting untuk dimiliki oleh UMKM. Dengan mengetahuinya laporan laba rugi yang benar, UKMK dapar memonitor apakah bisnisnya untung atau rugi pada bulan berjalan. Pada masa waktu tertentu UMKM dapat mengevaluasi laporan laba rugi tersebut agar dapat mengetahui tren penjualannya. Adapun contoh dari laporan laba rugi UMKM yang dibina pada pogram ini adalah sebagai berikut.

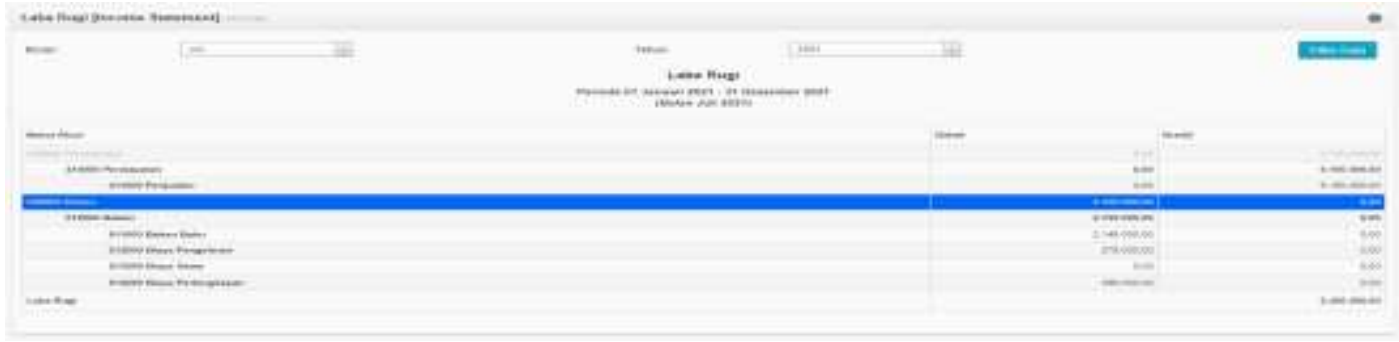

Gambar 9. Laporan Laba Rugi

c. Neraca

Neraca merupakan laporan akhir yang difasilitasi pada sistem keuangan ini. Neraca dapat digunakan oleh UMKM untuk mengevaluasi sejauh mana asset yang dimiliki dibandingkan dengan hutang usahanya. Dari laporan neraca tersebut UMKM dapat mengevaluasi apabila terjadi nilai hutang lebih besar dari pada modal maka UMKM harus berusaha untuk melunasi hutangnya. Demikian juga dengan asset, apabila asset tidak lancer lebih banyak nialinya dibandingkan dengan asset lancer maka hal tersebut dapat menjadi peluang untuk menginvestasikan pada usaha lainnya. Adapun contoh dari Neraca UMKM yang dibina pda program ini adalah sebagai berikut:

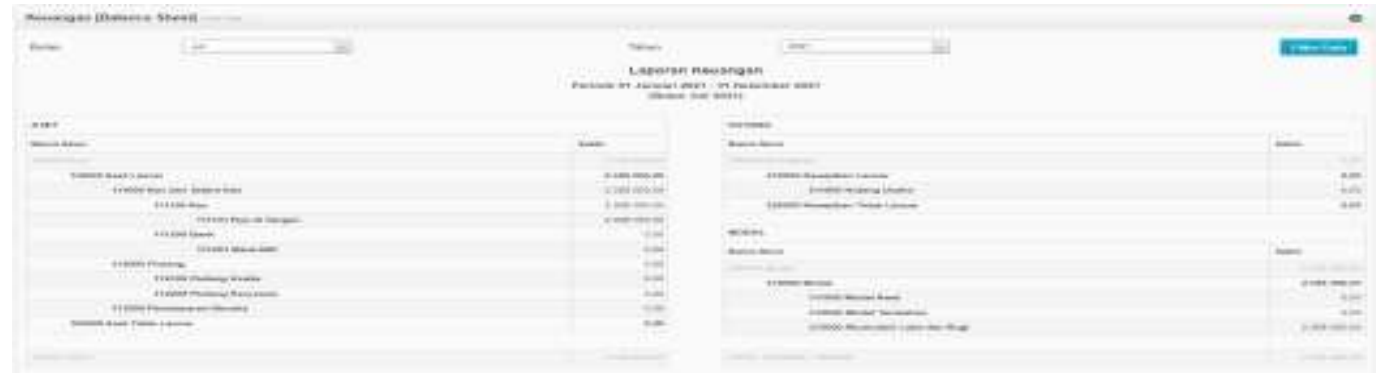

Gambar 10. Neraca

4) Pendampingan

Pendampingan yang dilakukan yakni dengan memonitor transaksi yang di input oleh UMKM. Apabila terjadi kesalahan pada penginputan maka UMKM akan diinformasikan dan diberikan pemahaman input transaksi yang benar. Selain itu pendampingan juga melakukan evaluasi laporan keuangan. Sehinga UMKM dapat mengetahui hal-hal yang membutuhkan perhatian khusus. Hal tersebut diantaranya adalah fluktuasi transaksi-transaksi. Dengan pendampingan UMKM diberitahukan pada waktu kapan saja penjualan turun. Selain itu juga UMKM diberitahukan mengenai piutang yang dimilikinya, sehingga UMKM dapat 
menindaklanjuti. Pada poin-poin biaya UMKM juga diinformasikan pada biaya mana saja yang terdapat kenaikan, sehingga UMKM dapat mengevaluasi dan dapat membuat alternatif sumber pembelian bahan baku pada masa yang akan datang. Dalam hal laporan keuangan UMKM juga diberikan pemahaman tentang cara menggunakan dan membaca laporan, sehingga UMKM dapat menjadikan laporan keuangan tersebut dasar untuk pengambilan keputusan dalam bisnisnya.

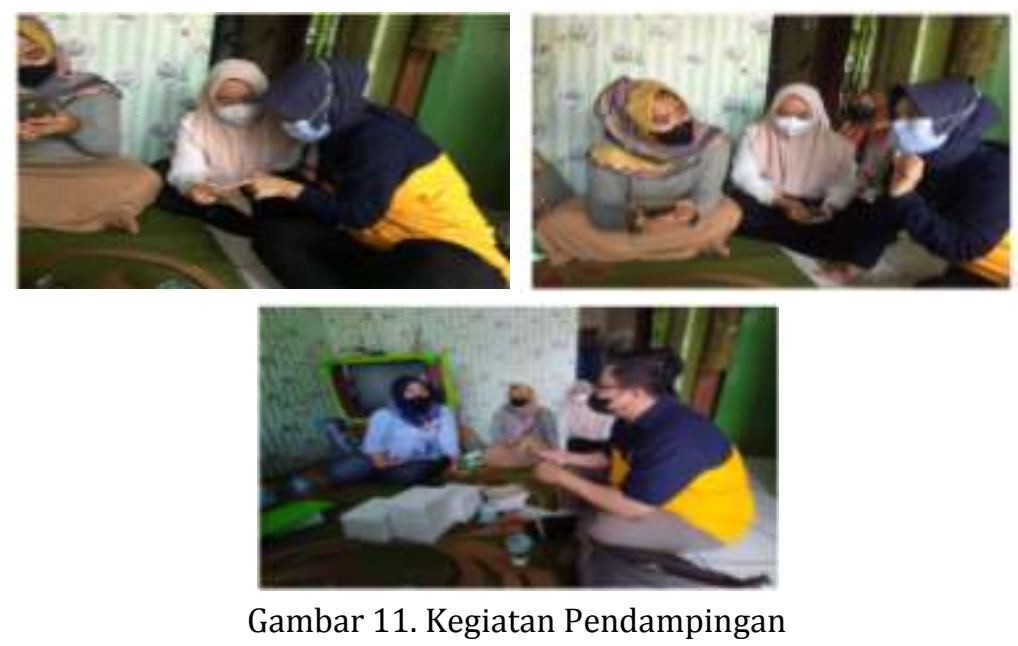

4. Indikator Keberhasilan

Adapun indikator keberhasilan kegiatan penerapan sistem keuangan digital ini adalah para pengelola UMKM sudah dapat melakukan input transaksi dan membaca laporan keuangan. Selain itu, tolok ukur dalam evaluasi program ini, UMKM telah melakukan secara rutin dan teratur baik dalam hal input transaksi maupun melakukan pemantauan terhadap laporan keuangannya. Diharapkan UMKM juga dapat secara mandiri mengevaluasi kondisi keuangan bisnisnya. Sehingga UMKM dapat memutuskan langkah bisnis yang tepat pada masa yang akan datang. Dalam pelaksanaan program pengabdian kepada masyarakat ini, tim PKM membuatkan aktivitas kunci bagi UMKM untuk mencapai tujuan program. Adapun tabel yang digunakan dalam penilaian pada UMKM tersebut adalah sebagai berikut:

Tabel 1. Penilaian Rata-rata Akivitas Kunci UMKM Pada Progam Pengabdian Kepada Masyarakat

\begin{tabular}{|c|c|c|c|c|c|c|c|c|c|}
\hline \multirow[t]{2}{*}{ No } & \multirow[t]{2}{*}{ Aktivitas } & \multicolumn{4}{|c|}{$\begin{array}{l}\text { Rata-rata Jumlah } \\
\text { Input Transaksi }\end{array}$} & \multirow{2}{*}{$\begin{array}{c}\text { Total } \\
\text { Input } \\
\text { Transaksi }\end{array}$} & \multirow{2}{*}{$\begin{array}{c}\text { Target } \\
\text { Input } \\
\text { Transaksi }\end{array}$} & \multirow{2}{*}{$\begin{array}{l}\text { Skor } \\
\text { Akhir } \\
(\%)\end{array}$} & \multirow[t]{2}{*}{ Keterangan } \\
\hline & & $\begin{array}{c}\mathrm{Mg} \\
1\end{array}$ & $\begin{array}{c}\mathrm{Mg} \\
2\end{array}$ & $\begin{array}{c}\mathrm{Mg} \\
3\end{array}$ & $\begin{array}{c}\mathrm{Mg} \\
4\end{array}$ & & & & \\
\hline 1 & $\begin{array}{l}\text { Menginput } \\
\text { transaksi } \\
\text { harian }\end{array}$ & 26 & 30 & 32 & 35 & 132 & 140 & 88 & $\begin{array}{l}\text { Input transaksi } \\
\text { pada aplikasi } \\
\text { (kuantitas dan } \\
\text { kualitas) dinilai } \\
\text { sangat baik }\end{array}$ \\
\hline 2 & $\begin{array}{l}\text { Evaluasi } \\
\text { laporan } \\
\text { keuangan }\end{array}$ & 2 & 2 & 3 & 4 & 12 & 16 & 69 & $\begin{array}{l}\text { Evaluasi laporan } \\
\text { keuangan untuk } \\
\text { pengambilan } \\
\text { keputusan } \\
\text { (kuantitas dan } \\
\text { kualitas) dinilai } \\
\text { baik }\end{array}$ \\
\hline
\end{tabular}

Keterangan:

- $\quad$ Mg diartikan minggu

- $\quad$ Skor akhir $\leq 25$ dinilai kurang

- Skor akhir 26-50 dinilai cukup

- $\quad$ Skor akhir 51-75 dinilai baik

- $\quad$ Skor akhir $\geq 76$ dinilai sangat baik 
Dari penilaian di atas, UMKM dapat merubah sikapnya dalam menggunakan sistem keuangan yang pada awalnya UMKM tidak memiliki keterampilan menginput transaksi keuangan saat ini UMKM menjadi terampil untuk melakukannya posting guna mendukung perkembangan usahanya.

\section{KESIMPULAN}

Dari kegiatan pengabdian kepada masyarakat ini dapat disimpulkan kedalam beberapa poin, diantaranya adalah sebegai berikut:

a. UMKM dapat melakukan input traksaksi penerimaan dan pengeluaran sesuai dengan transaksi bisnis.

b. UMKM dapat melakukan input transaksi dan melihat laporan keuangan secara real tim online karena sistem keuangan berbasis website.

c. UMKM dapat membaca laporan keuangan dengan benar.

d. Adanya perubahan perilaku UMKM dalam hal mencatat transaksi bisnis.

e. Hal yang perlu kembangkan dalam program ini adalah sistem keuangan masih berbasis website dan belum berbasis aplikasi pada android. Hal ini dapt menjadi perhatian khusus agar UMKM lebih mudah dalam menggunakan sistem keuangan ini.

\section{UCAPAN TERIMA KASIH}

Penulis mengucapkan terima kasih kepada Universitas Jenderal Achmad Yani yang telah memberi dukungan financial terhadap pengabdian ini dan pihak pihak terkait lainnya yang tidak dapat disebutkan satu per satu.

\section{DAFTAR PUSTAKA}

Astuti, Ismadiyanti Purwaning. 2019. Pencatatan Keuangan Berbasis Digital Pada Paguyuban Pengrajin Sangkar Burung "Karya Mandiri. ISSN : 2615-2657. Seminar Hasil Pengabdian Masyarakat 2019 UNIVERSITAS AMIKOM Yogyakarta, 30 November

E. Kieso, Donald, Jerry J, Weygandt and Teery D. Warfield. (2011). Intermediate. Accounting, Edisi 12. Jakarta: Erlangga. Diana, Anasta

Fahmi, Irham. 2015. Pengantar Manajemen Keuangan Teori dan Soal Jawab. Bandung: Alfabeta.

Gitman, Lawrence. J. (2015). Principles of ManagementFinance 12th Edition. Boston. Pearson Education. Inc.

Ikatan Akuntansi Indonesia. PSAK No. 1 Tentang Laporan Keuangan- edisi revisi 2015. Penerbit Dewan Standar Akuntansi Keuangan: PT. Raja Grafindo

Janrosi, V. S. E. (2018). Persepsi Pelaku UMKM Dan Sosialisasi SAK EMKM Terhadap Diberlakukannya Laporan Keuangan Yang Berbasis SAK EMKM 1 Januari 2018. Jurnal Akuntansi Keuangan Dan Bisnis, 11(1), 55-66

Kasmir. (2018). Analisis Laporan Keuangan. Edisi Pertama Cetakan Kesebelas. . Jakarta: Raja Grafindo Persada.

Kurniawan, P. S. (2020). Sosialisasi dan Pelatihan Penyusunan Laporan Keuangan Berbasis Teknologi Informasi bagi Pelaku UMKM di Desa Belatungan, Pupuan, Bali. E-Dimas: Jurnal Pengabdian Kepada Masyarakat, 11(4), 440-446. https://doi.org/10.26877/edimas.v11i4.3981

Kusumaastuti, Purnama. 2015. Strategi dan Langkah-langkah UMKM dalam menghadapi Masyarakat Ekonomi ASEAN (MEA).

Mulyani, S. (2014). Faktor-Faktor Yang Mempengaruhi Kualitas Laporan Keuangan Pada Umkm Di Kabupaten Kudus Kata. Jurnal Dinamika Ekonomi \& Bisnis, 11(2), 137-150

Mulyawan, Setia. (2015). Manajemen Keuangan. Bandung: CV Pustaka Setia.

Musthafa. (2017). Manajemen Keuangan. Yogyakarta: CV.Andi Offset. 
Nasution, N., \& Hasan. M. A. (2021). IBMAplikasi Keuangan Pada Sekolah Dasar Luhuring Budi Kecamatan Rumbai. DINAMISIA: Jurnal Pengabdian Kepada Masyarakat. Vol. 5, No. 3 Juni 2021, Hal. 754-762. Vol. 5, No. 3 Juni 2021, Hal. 754-762

Ningtiyas, J. D. A. (2017). Penyusunan Laporan Keuangan UMKM Berdasarkan Standar Akuntansi Keuangan Entitas Mikro, Kecil dan Menengah (SAKEMKM) (Study Kasus Di UMKM Bintang Malam Pekalongan). Riset \& Jurnal Akuntansi, 2(1), 11-17

Rencana Program Investasi Jangka Menengah (RPIJM) Kabupaten Bandung Barat 2015-2019, dari https://sippa.ciptakarya.pu.go.id/sippa_online/ws_file/dokumen/rpi2jm/DOCRPIJM_87dd9 7983f_BAB\%20I1.\%20PENDAHULUAN.pdf

Sadeli, L. M. (2011). Dasar Dasar Akuntansi (1 (7)). Jakarta: Bumi Aksara.

Savitri, R. V., \& Saifudin, .. (2018). Pencatatan Akuntansi Pada Usaha Mikro Kecil Dan Menengah (Studi Pada Umkm Mr. Pelangi Semarang). JMBI UNSRAT (Jurnal Ilmiah Manajemen Bisnis Dan Inovasi Universitas Sam Ratulangi)., 5(2), 117-125. https://doi.org/10.35794/jmbi.v5i2. 20808

Sedyastuti, K. (2018). Analisis Pemberdayaan UMKM Dan Peningkatan Daya Saing Dalam Kancah Pasar Global. INOBIS: Jurnal Inovasi Bisnis Dan Manajemen Indonesia, 2(1), 117-127. https://doi.org/10.31842/jurnalinobis.v2i1.65

Setiyawati, Y., \& Hermawan, S. (2018). Persepsi Pemilik Dan Pengetahuan Akuntansi Pelaku Usaha Mikro Kecil Dan Menengah (Umkm) Atas Penyusunan Laporan Keuangan. Riset Akuntansi Dan Keuangan Indonesia, 3(2), 161-204. https://doi.org/10.23917/reaksi.v3i2.6629

Singal, Ribka Agustine dan Sherly Pinatik. 2015. Evaluasi Penyusunan Laporan Laba Rugi dan Neraca Berdasarkan SAK ETAP pada PT. Karunia Multiguna Abadi. Jurnal Riset Ekonomi, Manajemen, Bisnis dan Akuntansi Vol. 3 No. 4 (395-403).

Solikah, Mar'atus; Puji Astuti dan Dyah Ayu Paramitha. 2017. Analisis Faktor-Faktor yang Mempengaruhi Persepsi Wirausahawan Terhadap Pentingnya Pembukuan dan Laporan Keuangan. Jurnal Akuntansi \& Ekonmi FE. UN PGRI Kediri Vol. 2 No. 2 (12-21)

Wahyuningsih, D. dan A. F. (2019). Rancangan Model Tata Kelola Keuangan UMKM Sekolah tinggi Ilmu Ekonomi Kesatuan Bogor Jurnal IKRA-ITH Humaniora Vol 3 No 3 Bulan November 2019. $3(3), 83-92$. 